\title{
Impact of Implementing Blended Learning on Students' Interest and Motivation
}

\author{
Norasyikin Osman ${ }^{1, *}$, Mohd Isa Hamzah ${ }^{2}$ \\ ${ }^{1}$ Faculty of Languages and Communication, Universiti Sultan Zainal Abidin, Malaysia \\ ${ }^{2}$ Faculty of Education, National University Malaysia, Malaysia
}

Received January 29, 2020; Revised March 9, 2020; Accepted March 19, 2020

Copyright@2020 by authors, all rights reserved. Authors agree that this article remains permanently open access under the terms of the Creative Commons Attribution License 4.0 International License

\begin{abstract}
The advent of technology has brought changes to the Malaysian education system. One of the aspects which draws many attention is the integration of technology in Teaching and Learning. This includes the implementation of blended learning, which is given emphasis in the Malaysian Education Blueprint (Higher Education) 2015-2025. Blended learning is a combination of face-to-face learning and e-learning. As such, this research aims to investigate the impacts of implementing blended learning on students' interest and motivation. A total of 87 students underwent a blended-learning class for ten weeks. At the end of the class, they were asked to answer a survey on their interest and motivation in relation to the attended class. They were also requested to write a reflection in the last class where five students were later interviewed for further clarification. Findings show that students have higher level of interest and motivation when participating in a blended learning classes. Hence, the implementation of blended learning has its advantages and ought to be further enhanced for its ability to draw students' interest and motivation in their learning.
\end{abstract}

Keywords Blended Learning, E-Learning, Impact, Interest, Motivation

\section{Introduction}

Blended learning is one of the many ways of learning, which is quickly drawing attention in this digital age. Most teaching and learning processes to date, are actively implementing blended learning aiming to increase its quality, besides to be at par with technological advancement. The advent of technology is inevitable, in fact, ought to be received well. However, it can be improved in order to suit situation and context. In teaching and learning, a full coorporation of technology is not an effective choice since human touch is necessary and uncomparable to the advanced technology. Hence, blended learning is observed to be a better option for its combination of latest modern technology and human touch. In the process of teaching and learning, among the many psychological aspects which arre often discussed is the aspect of interest and motivation. These two aspects play a vital role at driving excellence within any student. Nonetheless, students' level of reception towards blended learning from the aspect of interest and motivation remains unidentified. Upon observing such a situation, this research will discuss in relation to the impact of implementing blended learning on students' interest and motivation.

\section{Blended Learning}

According to Tayebinik (2012) and Zhang \& Han ( 2012), blended learning first appeared circa 2001. Its appearance was due to the weaknesses in implementing e-learning as a total. Among identified weaknesses are students who are independent learners, often feel lonely and isolated. This is because students are only required to sit before a computer and interaction with it. Besides that, students also feel as if they are abandoned, which hence leads to procrastinate their given tasks. When learning independently, which also takes place through e-learning websites, students begin to feel unattended and begin to feel at ease doing anything. Lack of skills is also a contributing factor to the weakness of e-learning as a total ( Graham 2003; McDonald 2008; Precel, Eshet-alkalai \& Alberton 2009). What is evidently lacking in learning through e-learning is aimed to be compensated through the implementation of blended learning.

Blended learning is defined in numerous ways. In general, blended learning is categorized into three types based on Sharma (2010), Oliver, and Trigwell (2005), 
Graham, Allen, and Ure (2003). These categories are (i) the combination of face-to-face learning and web-incorporation, (ii) the combination of technology, (iii) the combination of methodology. Nonetheless, the often quoted definition is the combination of face-to-face and e-learning (Bliuc, Goodyear \& Ellis, 2007; Graham, 2003; Thorne, 2003 ; Sharma \& Barrett, 2007). Blended learning in general has provided opportunities for most parties to improve the present implemented system of teaching and learning, which is the incorporation of face-to-face learning as a total, or the use of e-learning as a total. Combining the two forms of teaching and learning is known as blended learning, which is in line with the course or Programme objectives (Garrison \& Vaughan, 2008).

There are also numerous forms of implementing blended learning. In general, distribution of percentage for face-to-face learning and e-learning is approximately $30 \%-70 \%$ of course content appearing in the form of e-learning (Allen et. al., 2007). Nonetheless, there are different opinions like Dziuban, Hartman, and Moskal (2004) who highlight that distribution of percentage is not the primary factory but what lies more importance is to observe the situation that yields for the approach of combining active learning based on technology that is both classroom effective and socializing in nature.

Blended learning was first given attention in Malaysia when a research by Hisham, Che Su and Hassan (2006) was carried out on students perception of blended learning in UUM.. Findings show that blended learning is potential at replacing conventional learning. There were of course, other research such as that done by Farahiza A zizan (2010), Haryani, Wan Faezah, and Nor Aini (2012) and Wong Fok Fei et al., (2012). Sumarni and Raihan (2012) discussed students and teachers' reception of blended learning. In general, the research found out that students have positive opinions or perception on the implementation of blended learning.

\section{Interest and Motivation in Learning}

Interest is an internal factor that is closely related to man's desire at performance. As such, it is capable of influencing students' achievement. Students with interest in doing things are able to pursue such aims rigorously and with great diligence (Slameto, 2003). Interest plays an important role in the process of teaching and learning. High achievement are more likely obtained if one is interested in learning a particular subject (Hamdan \& Is mail, 2006). Interest is also said to be a combination between cognitive and affective process, which is based on positive emotion, personal values and possess owned knowledge that are in line with the subject interest (Tin, 2016).

Past research has looked into exploring students' interest in learning. This includes research done by Nik Rosila (2007) Zulzana, Mohamed, and Roslina, (2012) Hayden, Ouyang, Scinski, Olszewski, and Bielefeldt, (2011) and
Rafiza and Maryam (2017). This shows that interest is a significant aspect that needs researching on students' level of interest in his learning subject and needs to be at an accomodating level to ensure an effective learning process. Students with excellent level of interest are often able to master the subject learnt well. Interest plays a significant role in the process of teaching and learning because it is able to drive students' actions. They are more likely to take their learn ing seriously, provided that he is interested in the subject matter.

Meanwhile motivation is a stimulant, a driving factor that drives one to act to achieve a certain perfomance (Baharom \& Iliyas, 2009). Motivation also plays a role in ensuring students to be actively involved in the process of teaching and learning where it is in the latter process which gives meaning, benefit and pleasure (Kamarudin, 2010). Like interest, motivation is also an important aspect that is often researched. It is capable of influencing results or certain intended outcome. In general, motivated students are more determined to achieve a particular desire; they are more rigorous and least likely to feel afraid when dealing with challenges. In fact, they more motivated at achieving their goals due to the challenges. As a result, an outstanding achievement will be obtained by these high motivated students compared to those without motivation. The known past research on motivation includes Al-Ghamdi (2014), Anjomshoa and Sadighi (2015), Akdemir and Colakoglu (2008), Zaliza and Zaitul (2014). Nicholson (2013) in particular, emphasize that motivation is the determining factor for the success of mastering second language learning or foreign language learning. Teachers are among the individuals that play a dominant role in improving students' motivation.

Keller (2010) further observe motivation from a more detailed angle. He mainly divide motivation into four main aspects in his developement of a model for motivation, known as ACRS (Attention, Confidence, Relevan, Satisfaction). These four main aspects are attention, confidence, relevance and satisfaction.

\section{1) Attention}

Attention refers to students' tendency to apply taught concept or ideas. Attracting students' attention is an important element because it triggers motivation. When students are attracted to the taught topic, they are ready to provide time, give attention, etc.

\section{2) Relevance}

Relevance on the other hand is divided into three parts, which are goal orientation, motive matching, and habit. In general, the aspect of relevance associates what is taught with past experience and students' daily lifestyle.

\section{3) Confidence}

Confidence provides focus in order to create positive impression in achieving success among students. Students' 
level of confidence is often ass ociated with motivation and the amount of effort done in order to achieve the objectives of specific achievement.

\section{4) Satisfaction}

Satisfaction is an important element in motivation. Its attainment is necessary as a reward after undergoing learning. This satisfaction may vary in the form of achievement, credits or leisure. Feedback and reinforcement are important aspects when students appreciate results, so that they are more motivated to learn (Poulsen, Cisneros, \& Trust, 2008).

\section{Methodology}

This research aims to explore students' levels of interest and motivation after undergoing the Arabic language learning based on blended learning.

A total of 87 students were involved in this research. They are first year students of Universiti Sultan Zainal Abidin (UniSZA) who are registered for a course entitled Bahasa Arab Kebangsaan (National Arabic Language). These students underwent the course for ten weeks based on blended learning, which is a co mb ination of face-to-face classroom learning dan further engagement in a particular website provided by the university.

Data was collected using quantitative and qualitative approach. The research instruments mainly comprised of questionnaire and interview protocal where it was then supported by students' reflective notes. The questionnaire is divided into several sections, including demographic details, the four aspects of motivation (which are attention, confidence, relevance and satisfaction) where the final section comprised of students' interest after undergoing learning based on blended learning. Meanwhile, the interview protocal is made of questions related to students' interest and motivation.

The module based on blended learning contains eleven topics, which is easily accessible through Learning Management System (LMS ) as provided by the university. Students were requested to access e-learning in order to participate numerous learning activities such as downloading notes which are available in the form of multimedia, watching learning videos, conducting forum, answering quizzes, further reinforcing Arabic language proficiency through website links, reading dictionary and electronic translations. These provided materials in e-learning enables students for independent learning.

Upon using the module based on blended learning during the ten weeks, a questionnaire was distributed to obtain students' level of interest and motivation. Besides the questionnaire, six students were interviewed for additional information. Besides that, students were requested to write reflective notes on e-learning during the blended learning course.

There are three major limitations in this study that could be addressed in future research. First, the study only focused on the impact of imple menting blended learning on students' interest and motivation, secondly it merely concentrated on university students and thirdly this study was purely engaged in the field of social sciences particularly in learning Arabic language.

\section{Research Findings and Discussion}

Upon the distribution of questionnaires and later its collection, a process of data analysis was performed by using SPSS (Statistical Package for the Social Sciences). Analyzed data was observed based mean score for each construct in order to determine the students' level of interest and motivation on the module based on blended learning. In order to determine the obtained the mean score, Nunnally and Berstein's (1994) table of interpretation was used.

Table 1. Interpretation of mean score

\begin{tabular}{|l|l|}
\hline Min Value & Interpretation \\
\hline $1.00-2.00$ & Low \\
\hline $2.01-3.00$ & Moderately low \\
\hline $3.01-4.00$ & Moderately High \\
\hline $4.01-5.00$ & High \\
\hline
\end{tabular}

Source: Nunnally and Bernstein (1994)

Findings and discussions will cover two aspects which are students' interest and motivation in implementing blended learning.

\subsection{Interest}

Within the aspect of interest, a total of eight questions was issued. It is observed that the general mean score is 5.49. There are two items which obtain the highest score, which is 4.52 in relation to aspects of quality of materials and students' satis factory level during the Arabic language learning. This shows students have high level of interest when using the module based on blended learning. Table 2 details findings from the questionnaire with regards to interest. 
Table 2. Mean score on Interest

\begin{tabular}{|l|l|l|}
\hline No & Items & Min score \\
\hline 1. & I am interested in the materials used in the blended learning. & 4.48 \\
\hline 2. & In general, I can give attention during learning sessions. & 4.43 \\
\hline 3. & I feel that the materials stimulate my mind in order to further understand the learning materials. & 4.49 \\
\hline 4. & I am able to master the learning topics in the materials. & 4.44 \\
\hline 5. & The materials do not bore me. & 4.52 \\
\hline 6. & I am satisfied with learning Arabic language by using the materials. & 4.52 \\
\hline 7. & I hope to follow other similar learning materials such as this. & 4.57 \\
\hline 8. & $\begin{array}{l}\text { The use of multimedia elements such pictures, animation, background voice and interesting videos excites } \\
\text { me to further master Arabic language. }\end{array}$ & 4.48 \\
\hline & Overall & $\mathbf{4 . 4 9}$ \\
\hline
\end{tabular}

Besides the questionnaire, an interview was also conducted to observe students' level of interest in using the module. Based on the obtained data, students in general acknowledge the module attracted their interest.

Student 02 explained:

"The use of videos was interesting. To me, I like materials that appear to be animated or cartoon-like. When watching it, I am clearer. Besides that, the movement seems ....aaa and cartoons are more appealing lah...”(PLJ_TB_2: 1_18-20)

The use of multimedia elements in this module was also a factor that drew students' attention.

"It means there is audio, all that draws interest. I had fun, it excites me to further find out. Not just referring to books only, like a subject with books and letters only. No pictures right? If people look at such books filled with letters, they will also feel bored. (PLJ_TB_2:6_ 160-163)

Supporting data was also retrieved from students' reflective notes. Student 04 expressed himself, saying, "Thank you for sharing beneficial videos and using interesting elements that attract my interest to feel more excited to learn Arabic language.'(PLJ_RF_4)

Student 78 and 86 also expressed similarly, which are: "This video also increased my interest to master Arabic language because the video contains meaning, reading style which allows me to further understand Arabic language."(PLJ_RF_78) while "This video also draws my interest to master this subject."(PLJ_RF_86).

As discussed earlier, blended learning combines both face-to-face and e-learning. E-learning employs nu merous technological elements, particularly the use of multimedia. In general, mu ltimedia plays a significant role in creating a learning content that is interesting, fun, leaving out the boring elements. Hence, this will draw students' interest, which has been discussed by Chin (2009) and Wahyudin, Sutikno and Isa (2010), declaring that multimedia is capable of increasing students' interest while learning.

\subsection{Motivation}

The aspect of motivation has been scrutinized into four main constructs, which are attention, confidence, relevance and satisfaction based on Keller (2010). Within the construct of attention, there are twelve questions with a mean score that shows it is at the highest level, which is 4.36. The highest item with the score of 4.45 is as sortment of reading quotes, exercises, illustration, etc. Which helps maintain my attention on the material. This shows that interesting illustrations, combined with multimedia such as reading audio are capable of retaining students' attention on the module. Table 3 shows the mean score according to each item. 
Table 3. Mean score on Attention

\begin{tabular}{|l|l|l|}
\hline No & Items & Mean score \\
\hline 1 & There is something interesting about the beginning of an effective material, which gets my attention. & 4.24 \\
\hline 2 & The presentation style of the material helps me to continuously give attention. & 4.43 \\
\hline 3 & I am able to maint aining at tention/focus on the materials. & 4.41 \\
\hline 4 & Material design seems appealing. & 4.37 \\
\hline 5 & The information within the material is organized in a way that allows me to keep attention. & 4.41 \\
\hline 6 & This material contains items that excitemy curiousity. & 4.32 \\
\hline 7 & The total of repetition in the material does not bore me. & 4.32 \\
\hline 8 & I learn several new things, which are surprising or unexpected. & 4.36 \\
\hline 9 & Assortment of reading quotes, exercises, illustrations, and others, helps to retain my attention on the material. & 4.45 \\
\hline 10 & The presentation of material content is not boring. & 4.40 \\
\hline 11 & I am not bothered by the amount of words in each display. & 4.13 \\
\hline 12 & In general, this material draws attention. & 4.43 \\
\hline & O verall & $\mathbf{4 . 3 6}$ \\
\hline
\end{tabular}

For the construct on attention, the overall mean score is 4.23 , which is at the highest level. Items which are related to good organization which gives confidence to the students to further learn the module, are the highest score, which is 4.34 . Table 4 shows the overall mean score for confidence construct item.

Table 4. Score means on Confidence

\begin{tabular}{|l|l|l|}
\hline No & Items & Mean scores \\
\hline 1. & When I first saw this material, I assumed it would be easy to follow. & 4.15 \\
\hline 2. & This material is easy to understand as what I expected. & 4.32 \\
\hline 3. & After reading the introductory information, I was sure I knew what I would learn from the material. & 4.32 \\
\hline 4. & $\begin{array}{l}\text { There are pages with overwhelming information, yet it was not difficult to choose and remember the important } \\
\text { ideas. }\end{array}$ & 4.23 \\
\hline 5. & When using the material, I was sure that I would learn from its content. & 4.32 \\
\hline 6. & The exercises in the material were not difficult. & 4.29 \\
\hline 7. & After using the material several times, I was sure that I can pass the Arabic language test. & 4.34 \\
\hline 8. & I was not sure about a few parts of the material. & 3.66 \\
\hline 9. & Content organisation which is good, provides me the confidence to learn the material. & 4.43 \\
\hline & Overall & $\mathbf{4 . 2 3}$ \\
\hline
\end{tabular}

Overall score for the relevance construct is 4.37 . The ite $\mathrm{m}$ which scored the highest is material content, which is useful to the students, had the score of 4.56. Table 5 lists the details to the mean score for each item in the relevance construct.

Table 5. Mean score for Relevance

\begin{tabular}{|l|l|l|}
\hline No & Items & Mean score \\
\hline 1. & I am aware of the relationship between material content and things that I already know. & 4.21 \\
\hline 2. & This material plays a big role in learning Arabic language. & 4.44 \\
\hline 3. & Completing the material is important to me. & 4.46 \\
\hline 4. & There is a relationship bet ween material content and my interest. & 4.34 \\
\hline 5. & The content and presentation style of the material give an impression that its content is worth to know. & 4.39 \\
\hline 6. & The material is relevant to my needs, despite I already known most of it. & 4.23 \\
\hline 7. & I can associate the material content to things that I have seen, done or thought in my life. & 4.32 \\
\hline 8. & The material content is useful to me. & 4.56 \\
\hline & Overall & $\mathbf{4 . 3 7}$ \\
\hline
\end{tabular}


Table 6. Mean score on Satisfaction

\begin{tabular}{|l|l|l|}
\hline No & Items & Mean score \\
\hline 1. & Completing the exercise in the material gives me satisfaction on my learning. & 4.51 \\
\hline 2. & I am thrilled to use this material and wish to find out further about each topic for this material. & 4.45 \\
\hline 3. & I am genuinely excited to learn to usethis material. & 4.48 \\
\hline 4. & Feedback after each exercises or comments in the mat erials helps me to give a sense of reward for making the effort s. & 4.44 \\
\hline 5. & I am satisfied when I successfully complete the material content and activities. & 4.51 \\
\hline 6. & It is a joy to use a well-designed material. & 4.54 \\
\hline & Overall & $\mathbf{4 . 4 9}$ \\
\hline
\end{tabular}

For the construct of satis faction, the overall mean is 4.49 , which shows its high level. The item with the highest score is related to pleasure while using the well-designed material with the score value of 4.54 . The overall display of mean score obtained for each item is seen in Table 6.

Data retrieved from the interview shows that students acknowledge their feeling of joy over using the module, which is included in the element of motivation. Joyful feeling will stimu late students to feel spirited and excited at pursuing learning through this module. Student 2 from an interview expressed his feelings when using the module:

...whenever I c lick open e-kelip, I will definitely look at the Arabic course... I want to revise over what has been taught. I can also review my past quizzes. For example, after answering the quiz, there will remarks such excellent, etc., the cartoon will either appear as mumtaz (excellent) or jayyid (very good)... it is so much fun, excellent. (PLJ_TB_2;3_87-90)

Similarly, students' reflective notes also addressed the same is sue. According to the students, they feel wonderful because they can easily understand the conveyed content. According to Student 2, she had fun learning Arabic language, watching the video just now because there is audio. So later, I can improve my pronunciation correctly. When there is an oral test, tone and enunciation must be correct ..."(PLJ_RF_2). Similarly, a reflective note from student 34 recorded that, "when watching the provided video, I have fun continue listening because the video allows me to understand words in Arabic albeit it is limited " (PLJ_RF_34) while student 39's reflection wrote, "with videos such as this, I can have fun while exploring the subject"(PLJ_RF_39).

Excitement is one of the many emotions experienced by the students while attending to this module. According to student 16's reflective note, he wrote, "Thank you for sharing the video which is mean ingful and beneficial to me, and a pact with knowledge that energizes me to learn Arabic language" (PLJ_RF_16).

Likewise, student 77 's reflection expressed, “...both, my clas sroom learning and video watching have stimulated me to be eager and high-spirited to learn other Arabic words" (PLJ_RF_77). In a re flective note by student 87 , he similarly expressed that "the module has helped my friends and me to understand Arabic language and it is easy to understand. There are also new Arabic words, which excites me to learn this language" (PLJ_RF_87).

In general, findings from this research shows motivated students when attending this module. The use of e-learning in the process of teaching and learning basically improves students' motivation because the element of e-learning is interactive by nature, besides the fact that it is effective and dynamic. The main role of e-learning at providing motivation has been discussed by Sharma and Barret (2007) and Ghazali Yusri et al. (2012). According to Novo-Corti, Varela-Candamio, and Ramil-Díaz, (2013) as well as Christensen (2003), blended learning is far more effective, gearing students to be more motivated compared with face-to-face learning in total. This is parallel with other research, such as that done by Liu and Yu (2012), Hubackova, Semradova and Klimova (2011) and Wu and Hwang (2010) who have consensus claiming that blended learning motivates students' learning.

\section{Summary and Recommendation}

The administration of blended learning is quickly turning into a necessity in the present world, especially at the level of higher learning. This is due to the nature of blended learning that celebrates the present technological advancement without neglecting face-to-face learning, which has been used since then. Numerous benefits are evident in blended learning, including its flexibility, appealing for its multimedia element, interactive nature, celebration of individual difference, accessibility of materials and the retainment of physical meeting between student and teacher. Technological use in daily life is without doubt, inevitable. In fact, its avoidance is a lost. Among the many educational initiatives, implementing tehcnological use regorously into the process of teaching and learning (PdP) is seen as a timely effort. Most students are equipped with the skills to use technology As such, it is a loss if technology is not used in teaching and learning where both teachers and students have such skills.

Based on the research, the implementation of blended learning also gives positive impact on students' interest and motivation in learning. Students acknowledge the 
administered course, which was done using blended learning, is drawing their attention. Similarly, they are also motivated when undergoing the course. Findings show that blended learning has a big potential for further development and later use in different levels of learning, including primary and secondary schools.

The result from this study shows a few practical implications. The implementation of this blended learning needs to be enhanced at higher learning level so that students can benefit greatly. Education institutions should fully support the implementation by rendering adequate knowledge, skills and training to the teachers. For teachers, they are suggested to actively carry out blended learning during lessons. As has been suggested, blended learning can increase interest and motivation. Thus, this will further improve students' achievement.

\section{Conclusions}

This research has discussed the impact of implementing blended learning on students' interest and motivation. Blended learning is a combination of face-to-face learning and e-learning, which is observed to have its own benefits, especially in the present age of technological advancement. This research found blended learning gives a positive impact on students' interest and motivation. Findings show students are interested and motivated when following a module based on blended learning.

\section{REFERENCES}

[1] Akdemir, O., \& Colakoglu, O. M. (2008, June). Measuring motivation in the instruction developed for blended courses. In EdMedia: World Conference on Educational Media and Technology (pp. 10-15). Association for the Advancement of Computing in Education (AACE).

[2] Al-Ghamdi, A. (2014). The role of motivation as a single factor in second language learning. Arecls, 11, 1-14.,

[3] Allen, I. E., Seaman, J., \& Garrett, R. (2007). Blending in: The extent and promise of blended education in the United States. Sloan Consortium. PO Box 1238, Newburyport, MA 01950.

[4] Anjomshoa, L., \& Sadighi, F. (2015). The importance of motivation in second language acquisition. International Journal on Studies in English Language and Literature (IJSELL), 3(2), 126-137.,

[5] Baharom Mohamad, Iliyas Hashim. (2009). Bagaimana memotivasi pelajar: Teori, Konsep dan kepentingan. Kuala Lumpur: PTS profesional.

[6] Bliuc, A. M., Goody ear, P., \& Ellis, R. A. (2007). Research focus and methodological choices in studies into students' experiences of blended learning in higher education. The Internet and Higher Education, 10(4), 231-244.
[7] Christensen, T. K. (2003). Case 1: Finding the balance: Constructivist pedagogy in a blended course. Quarterly Review of Distance Education, 4(3), 235-43.

[8] Dziuban, C., Hartman, J., \& Moskal, P. (2004). Blended learning. Educause Centre for Applied Research Bulletin 7(1): 12 .

[9] Farahiza Zaihan Azizan (2010). Blended learning in higher education institution in Malaysia. In Proceedings of regional conference on knowled ge integration in ICT (Vol. 2010, pp. 454-466).

[10] Garrison, D. R., \& Vaughan, N. D. (2008). Blended learning in higher education: Framework, principles, and guidelines. John Wiley \& Sons.

[11] Ghazali Yusri, Nik Mohd Rahimi, Parilah M. Shah, Muhammad Arsyad Abdul Majid, Wan Haslina Wah. (2012). Penggunaan bahan pembelajaran dalam kursus bahasa Arab. GEMA: Online Journal of Language Studies $12(1)$.

[12] Graham, C. R., Allen, S., \& Ure, D. (2003). Blended learning environments: A review of the research literature. Unpublished manuscript, Provo, UT

[13] Hamdan, A. R., Sihes, A. J., \& Ismail, M. (2006). Tahap Minat, Pengetahuan Dan Kemahiran, Latihan Guru Dan Beban Tugas Guru Program Pemulihan Khas Sekolah Kebangsaan Daerah Pontian, Johor. Universiti Teknologi Malay sia.)

[14] Hary ani Haron, Wan Faezah Abbas, Nor Aini Abd Rahman. (2012). The Adoption of Blended Learning among Malavsian Academicians. Procedia-Social and Behavioral Sciences, 67: 175-181.

[15] Hayden, K., Ouy ang, Y., Scinski, L., Olszewski, B. \& Bielefeldt. T. (2011). Increasing Student Interest and Attitudes in STEM: Professional Development and Activities to Engage and Inspire Learners. Contemporary Issues in Technologv and Teacher Education. 11(1). 47-69. Wavnesville. NC USA: Society for Information Technology \& Teacher Education

[16] Hisham Dzakiria, Che Su Mustafa \& Hassan Abu Bakar. (2006). Moving forward with Blended Learning (BL) as a pedago gical alternative to traditional classroom learning. Malaysian Online Journal of Instructional Technology (MOJIT) 3(1): 11-18.

[17] Hubackova. S.. Semradova. I.. \& Klimova. B. F. (2011). Blended learning in a foreign language teaching. Procedia-Social and Behavioral Sciences 28: 281-285.

[18] Kamarudin Husin. (2010). Psikologi pembelajaran. Kuala Lumpur: Utusan Publication.

[19] Keller. J. M. (2010). Motivational design for learning and performance: The ARCS model approach. Springer Science $\&$ Business Media.

[20] Liu, W., \& Yu. H. (2012). Effectiveness Study of English Learning in Blended Learning Environment. Theory and Practice in Language Studies 2(3): 524-530.

[21] Nicholson. S. J. (2013). Influencing motivation in the foreign language classroom. Journal of International Education Research, 9(3), 277. 
[22] Nik Rosila Nik Yaacob. (2007). Penguasaan iawi dan hubunganny a dengan minat dan pencapaian pelajar dalam pendidikan Islam. Malaysian Journal of Educators and Education, 22, 161-172.

[23] Novo-Corti, I., Varela-Candamio, L., \& Ramil-DíAz, M. (2013). E-learning and face to face mixed methodology: Evaluating effectiveness of e-learning and perceived satisfaction for a microeconomic course using the Moodle platform. Computers in Human Behavior, 29(2): 410-415.

[24] Nunnally, J. C.\& Bernstein, I. H. (1994). Psychometric theory. New York: McGraw-Hill.

[25] Oliver, M., \& Trigwell, K. (2005). Can 'Blended Learning'Be Redeemed? E-learning and Digital Media 2(1): $17-26$.

[26] Poulsen, A., Lam, K., Cisneros, S., \& Trust, T. (2008). ARCS model of motivational design. Retrieved March, 21, 2011.

[27] Precel. K.. Eshet-Alkalai. Y.. \& Alberton. Y. (2009). Pedago gical and desiøn aspects of a blended learning course. The International Review of Research in Open and Distance Learning 10(2).

[28] Rafiza Abdul Razak \& Maryam Abdul Rahman (2017). Pembinaan media pengaiaran berasaskan multimedia di kalangan guru ICTL. JuKu: Jurnal Kurikulum \& Pengajaran Asia Pasifik, 1(2), 20-31.

[29] Sharma. P. (2010). Blended learning. ELT journal 64(4):456-458.

[30] Sharma. P.. \& Barrett. B. (2007). Blended learning: Using technology in and beyond the language classroom. Oxford: Macmillan.

[31] Slameto. (2003). Belajar dan Faktor-faktor yang Mempengaruhinya. Jakarta: PT Rineka Cipta.)).

[32] Sumarni Maulan \& Raihan Ibrahim. (2012). The Teaching and Learning of En glish For Academic Purboses in Blended Environment. Procedia-Social and Behavioral Sciences 67: 561-570.

[33] Tayebinik, M. (2012). Blended Learning or E-learning? International Magazine on Advances in Computer Science and Telecommunications (IMACST), hlm. 103-110.

[34] Thorne, K. (2003). Blended Learning: How to Integrate Online and Traditional Learning. London: Kogan Page Limited.

[35] Tin, T. B. (2016). Stimulating Student Interest in Lan guage Learning. In Stimulating Student Interest in Language Learning (pp.275-315). Palgrave Macmillan, London)

[36] Wong. F. F.. Thang. S. M.. Latif. H.. Aziz.M. S. A.. \& Noor N. M. (2012). A blended apbroach in teaching an EAP course: Malaysian instructors' perceptions of the new course materials. 3L: Language. Linguistics and Literature. The Southeast Asian Journal of English Language Studies 18(3): 103-117.

[37] Wu, W., \& Hwang, L. Y. (2010). The effectiveness of e-learning for blended courses in colleges: A multi-level empirical study. International Journal of Electronic Business Management 8(4): 312.
[38] Zaliza Mohamad Nasira, Zaitul Azma Zainon Hamzah (2014). Sikap dan motivasi pelajar terhadap pembelajaran Bahasa Melayu. Procedia-Social and Behavioral Sciences, 134, 408-415.

[39] Zhang. W.. \& Han. C. (2012). A Case Studv of the Application of a Blended Learning Approach to Web-based College En glish Teaching Platform in a Medical University in Eastern China. Theory and Practice in Language Studies 2(9): 1961-1970.

[40] Zulzana Zulkarnain. Mohamed Saim. \& Roslina Abu Talib. (2012). Hubungan antara minat. sikan den gan pencabaian pelajar dalam kursus CC301-Quantity Measurement. Politeknik Port Dickson. 